\title{
Evaluating the Effect of Different Planting Dates on Panicle Growth Trend and Performance of Rice Varieties in Khuzestan Region, Iran
}

KAVEH LIMOUCHI

Ph.D Agronomy. Young Researchers and Elite Club, Dezful Branch, Islamic Azad University, Dezful, Iran.

Email:Kavehlimouchi@yahoo.com

\begin{abstract}
This study was aimed at evaluating the effect of different planting dates on the panicle growth trend (length, weight, and branches of panicle) and the performance of rice varieties in the north of Khuzestan province with east latitude of $48^{\circ}: 28{ }^{\circ}$ and north longitude of $31^{\circ}: 500^{\circ}$ executed as spilt plots in the form of randomized complete blocks with three repetitions. Main factor was the date of planting at three levels (June $5^{\text {th }}$, June $20^{\text {th }}$, and July $5^{\text {th }}$ ) and the secondary factor includes the varieties of red Anbori (tall and short grains), and Champa. Results indicated that the maximum performance of the seed, floret in panicle, and weight belonged to the date of July $5^{\text {th }}$ and the maximum length of panicle and branches, without significant difference, be longed to the second date of planting. evaluating the growth trend, maximum increase (rate of growth) of the dry weight and number of floret was due to the more-appropriate heat and the reduction of sterility as well as a more demand for non-structural carbohydrates (unlike the planting date of June $\left.5^{\text {th }}\right)$ in the planting date of July $5^{\text {th }}$, but the length of panicle had its most growth rate in the first two planting dates, while the number of branches was not affected by the date of planting. Among the varieties, Champa, with an average of 3795/4 $\mathrm{kg} / \mathrm{ha}$, had the maximum efficiency. Based on the results of this study, by focusing on the modifying objectives to increase the dry weight of the panicle, because of its positive and high correlation $\left(0 / 759^{* *}\right)$, increase of the rice seed`s efficiency can be hopefully predicted.
\end{abstract}

\section{DOI: https://dx.doi.org/10.4314/jasem.v22i9.06}

Copyright: Copyright $\odot 2018$ Kaveh. This is an open access article distributed under the Creative Commons Attribution License (CCL), which permits unrestricted use, distribution, and reproduction in any medium, provided the original work is properly cited.

Dates: Received: 15 February 2018; Revised: 09 August 2018; Accepted: 22 August 2018

Keywords: dates of planting, rice, growth trend, panicle

Rice is one of the strategic yields of the world especially in Asia, and, currently, is the food of 3 billion people around the world (Emam, 2007). Two or three times of rice harvest per year is one method to increase its production in some of the world's rice rich regions (Noor Mohammadi et al., 1997). In this regard, because of its role in the optimal use of managerial and environmental factors, rice planting in an inappropriate time is undeniable in order to increase the production (Noor Miohammadi et al., 1997). Appropriate date of planting optimizes the efficiency of using factors affecting the performance (Ali and Rahman, 1992). Steven and Linscombe (2004) stated that the date of planting and heat have an important effect on the yield growth and rice performance because in two regions of Louisiana, one at southwest and the other at northeast, the southwest one had a performance of more 8/5 tons/ha in late March. In addition, as the planting delayed, the performance has also reduced and, at the planting date of late March, reduction of performance was observed ( $5 / 2$ tons/ha). Then, as the planting delayed in mid-April, the performance of seed has increased to $7 / 2$ tons/ha and all subsequent dates had a linear reduction of performance. Fow et al. (2004), in Australia, evaluating 103 rice varieties from different origins and comparing the effects of plant's exposure - to - low heat and water heat time on the sterility and performance of rice, resulted that the effect of low heat on the plant's sterility and growth is not limited to the flowering time and the exposure - to - low heat time affect the delay in flowering and sterility of the plant. Siyadat et al. (2001), evaluating the Veysian region of Khoram Abad city, concluded that the best date of planting is April $12^{\text {th }}$, and the best variety is the Blacktail (Dom Siah) with a performance of $3265 \mathrm{~kg}$ in this date. Modification of planting techniques such as changing the planting date was introduced as an effective strategy for a quantitative and qualitative increase of growth (Farrell et al., 2004). Limochi (2012), evaluating the different dates of planting on 10 varieties, introduced the reduction of varieties` growth period as an important factor affecting the reduction of performance, which was because of the reduction of non-structural carbohydrate transportation to the main reservoir (the seed ). In addition, evaluating the correlation of performance and properties related to the stem, concluded that the maximum positive and significant correlation is between the seed performance and stem weight $\left(0 / 626^{* *}\right)$. Although the 
rate of the yield growth at the developing stage affect the rice seed performance, its amount, two weeks before heading, has critical effects on the final rice seed performance, so maximizing its amount during this period is one of the important managerial and modifying objectives to achieve the maximum seed (Horie et al., 2003). Erfani and Nasiri (2000), studying some of the morphologic and physiologic properties affecting the seed of rice varieties, stated that the leaf surface index in the modified varieties was more than the native varieties during the growth stage especially at flowering. Gilani (2010), evaluating the trend of panicle filling, resulted that the increase of the panicle`s dry weight at delayed planting date $(2 / 25)$, because of the appropriateness of the growth conditions, was more than the previous plantings. This study was aimed at evaluating the effect of different planting dates on the panicle's trend of changes and performance of rice varieties at Khuzestan conditions in order to identify the physiologic reaction of the tolerant or heat-sensitive mechanisms in addition to provide functional properties to modify the planted rice varieties and the role of the studied properties in increasing the performance.

\section{MATERIALS AND METHODS}

This study reviews the panicle growth trend and yield of rice in the Khuzestan province with longitude $48^{\circ}$, $28^{\prime \prime}$ and latitude $31^{\circ}, 50^{\prime \prime}$ with $33 \mathrm{~m}$ above sea level, clay soil loam $\mathrm{pH}$ near 7.2 and electrical conductivity of $3.1 \mathrm{~m}$ mous $/ \mathrm{cm}$. Tested in 2011 as a split plot randomized complete block design with three replications in plots of size $2.5 \times 4 \mathrm{~m}$ was carried out.
Main planting date at Level 5 in the 25 May $\left(\mathrm{d}_{1}\right), 9$ june $\left(\mathrm{d}_{2}\right)$ and 25 June $\left(\mathrm{d}_{3}\right)$ as main plots and cultivars include: Red Anbori feet long $\left(\mathrm{V}_{1}\right)$, Champa $\left(\mathrm{V}_{2}\right)$, Red Anbori legged short $\left(\mathrm{V}_{3}\right)$, were considered as subplots. average monthly temperature of the May 2010 (the first planting date) to October 2010 (the end), respectively, 37.1, 38.3, 39.2, 36.5, 32 and $24.4^{\circ} \mathrm{C}$, respectively. rate of consumption of $80 \mathrm{~kg}$ seed/hac and a sprinkling of seeds germinated in soil saturated with water and a combination of hand weeding and weed control using 2-4 -D, the value 1.5 lit/hac tooked control. The nutrient requirements based on soil test (Table 1) were determined and used, the source of phosphorus, ammonium phosphate and $50 \mathrm{~kg} / \mathrm{ha}, 100$ $\mathrm{kg} / \mathrm{ha}$ of potash from potash and zinc sulphate $40 \mathrm{~kg} /$ ha basis and when sprayed before planting the seeds were consumed. Source of urea nitrogen per $180 \mathrm{~kg} /$ ha of which $50 \%$ in 3 to 4 leaf stage and $50 \%$ remaining at the end of tillering and the beginning of pregnancy were used. In order to measure the performance of seed (with $\% 14$ moisture) as $\% 85$ of the seeds were mature in the panicle, harvesting was carried out at 1/5 square meter wide from each plot with removing the margins. In each sampling carried out each three days and 10 days prior to the complete outbreak of panicle (beginning of panicle outbreak), 30 panicles were selected to determine the weight, length, number of floret and branches in the panicle, and to evaluate the changing trend before and after the outbreak of the panicle in order to carry out modifying processes, and also for identifying these properties role on the rate of final yield performance and the effect of different heat degrees during this period.

\begin{tabular}{lllllll}
\multicolumn{6}{l}{ Table 1: Average air temperature and precipitation during growth period of rice } \\
\hline Factor & May & June & July & August & September & October \\
\hline $\begin{array}{l}\text { Average air } \\
\text { temperature }\left({ }^{\circ} \mathrm{C}\right)\end{array}$ & 30.7 & 37.1 & 38.3 & 39.2 & 36.5 & 32 \\
Precipitation $(\mathrm{mm})$ & 8 & 0 & 0 & 0 & 0 & 6.3 \\
\hline
\end{tabular}

\section{RESULTS AND DISCUSSION}

Panicle length: panicle is one of the important components of the rice seed performance and any change in its number, length, weight, or components, affecting the panicle performance, can finally change the final performance of the plant. Thus, its trend of growth and weight during the natal and maturity period, ignoring the variety and managerial factors, is completely affected by continental factors such as temperature. Based on the results, no statistical difference was observed between panting dates and the interaction of two factors, but there was one at $\% 1$ level between the varieties (Table 2). In addition, observations showed that although the second date an then the first date of planting had more panicle length, but the properties above, among all dates of planting, were in one group. Among varieties, short leg Anbori had the minimum length of panicle. This is due to the varieties genotypic differences as, depending on the rice different genotypes, panicles with shorter length, but more compact, can reduce breathing and increase the efficiency of water use because it is the distal part with maximum presence in different heat conditions. One heat bearing mechanism is similar to the mentioned heat-sensitive varieties and can be a modifying objective because, under these conditions and because of the smaller cells with thicker wall, the power of cell water preservation (Table 3 ). These results are confirmed by Rafiee (2008) indicating that first date of planting has no effect on the panicle length. evaluating the trend of panicle growth during the natal period and before the panicle outbreak, it was 
resulted that, depending on the variety and date of planting, its amount is different seeing that the rate of the varieties` panicle length increase during the natal period at the first and second planting date is more than the third date. Because of the higher heat of the natal period during the first and second dates and significant reduction during the third one, it seems that high heat at the first and second dates and longer natal stage is necessary, which at the first date, because of the faster entrance of plant to the natal stage, and at second date, for increasing this period for G.D.D maximum absorb, there will be enough time for its growth. For varieties, the differences, regardless of the heat effect, are related to the genotype differences because the growth of panicle follows the overall process of plant growth, so the mentioned heat-sensitive varieties, because of a longer growth and more plant height, have a more panicle length. Because the panicle is physically the distal part of the plant exposed to more heat and has more breathing, it can be said that having shorter panicles can be mechanism of tolerance and getting rid of temperature. Producing panicles with appropriate length, but more compact, is a modifying objective in introducing the rice varieties because, under the conditions of having smaller cells and thicker wall, the power of cell water preservation would be increased. Based on the results, short leg and tall leg Anbori had the maximum changes and Champa had a relative and too little growth indicating that this variety has been less affected by different heat conditions and, however, had the maximum length of panicle among all varieties. other varieties had their maximum length of panicle at the second date of planting, because the climate condition was optimal they had minimum length of panicle at the third planting date for getting rid of heat stress; in addition, they had the maximum variations on days $9^{\text {th }}$ to $20^{\text {th }}$ after the beginning of panicle outbreak. After that, the trend of variations continued with a more moderate and finally fixed slope, which can be because of the start of seed filling in the panicle. These results (Figure 1) are confirmed by Gilani (2008).

Dry weight of the panicle: it is seen in the variance analysis table that the mentioned property is significant at $\% 1$ level between different dates of planting, and the interaction of both factors is significant at $\% 5$ level (Table 2). Because of the cause and effect relations above and their direct and high impact in increasing the performance, more breeding and modifying studies for this property is needed. Observing the table of average comparison, maximum amount was gained during the third date and the minimum one was gained during the first one, which is mostly because of the reduction of growth period especially natal growth during the first date. Among the varieties, tall leg Anbori had the heaviest panicle, which can be a result of the increase of length and secondary branches to all varieties (Tables 3 and 4). Results are confirmed by the evaluations above indicating the reduction of panicle's weight or reduction of growth period (Gilani and Moradi, 1997; Board et al., 2001; Emam, 2007; Naidu et al., 2004; Lewin et al., 2004), because ,during the first date of planting (June $5^{\text {th }}$ ), at which the growth period is shorter, the minimum panicle weight is gained, which is a result of the increase of environment heat and receiving the necessary G.D.D at natal period in addition to the faster reduction of growth period time. Panicle filling trend after its outbreak and during the maturity period indicates that the highest rate and effective duration of panicle filling is belonged to the third date of planting and the first one had the minimum rate and effective duration. It seems that high sterility is resulted from the high heat and intense limitation of demand for non-structural carbohydrates are the reasons of low rate, effective filling duration, panicle weight, and harvest indicator at the first planting date. In addition, among the varieties, short leg Anbori, because of the lower rate and shorter effective filling period, had a lower weight of panicle, while tall leg Anbori with a relatively higher rate than other varieties reached its maximum weight of panicle. At the third date of planting, for the short leg Anbori, increase of the rate of panicle weight was averagely occurred 9 days after the beginning of panicle outbreak and at two first dates of planting, 18 days after panicle outbreak, but with 3 days delay. Based on these results, in addition to plant growth conditions specially the yield's rate of growth before panicle outbreak, panicle`s potential and environmental heat affect the increase of panicle`s weight; in this regard, effective filling duration and its rate in addition of making a balance among them is too important. Results are confirmed by Morchi et al. (2002), indicating various panicle's dry weight in different varieties and by Yang et al. (2002) concerning the existence or nonexistence of slow or final stages in seed filling of rice varieties. It is also in consistence with the results concluded by Zakaria et al. (2002) concerning the reduction of panicle weight at high heat (Figure 1).

Number of floret in the panicle: number of seeds in the panicle is one of the most important components of seed performance in rice. Regardless of the floret physical location on the panicle, their number can be affected by the environmental heat during the maturity period. This study results indicated that there is a significant difference at $\% 5$ level between different dates of planting; no significant difference was observed between the varieties and interaction of two 
factors (Table 2). Among different dates of planting, floret number had an increasing trend from the first date to the third; this increase at the delaying dates of planting can be because of the environmental stress during the first date at natal stage, seeing that by the sterility of floret, assimilates, except of being transported to the seed, were transported to the plant base, and the tested varieties, at the current climate conditions, are mostly compatible with the third date $\left(\right.$ July $\left.5^{\text {th }}\right)$. Among the varieties, tall leg Anbori had the maximum number and because, always, some sterile floret are remained due to reasons such as balance and lack of photosynthetic materials allocation, making optimal conditions and appropriate management can be important to increase the number of seeds. These results (Table3) are confirmed by Gilani and Moraqdi (1997). Evaluating the trend of floret number variation on the panicle, maximum variations have occurred during the third date of planting; in addition, it had the maximum number of floret and, compared with the other dates, had its maximum rate of growth. Of course, this priority, with a little difference in Champa variety, has an intense increase at the first date and at the primary stages of growth, while its amount, at the final stages, was fewer than the third date. 15 days after the beginning of panicle outbreak, all varieties had their maximum number of floret; then, the curve slope, because of the seed filling and assimilate allocation, became fixed. From this stage onward the maximum effect should be on the increase of 1,000 seed weight, which can be improved by optimizing the managerial conditions. This difference among the planting dates was more in the tall leg Anbori indicating its effect and sensibility to different managerial conditions in addition, based on different dates of planting (different heat conditions), better use of managerial conditions is needed (Figure 1).

Number of branches in the panicle: table 2 indicated that the mentioned property has a significant difference between different planting dates and interaction of two factors; but, there was a significant difference at a \% 1 level between the varieties. Based on the average comparisons, maximum primary branches were belonged to Champa and tall leg Anbori. These results were confirmed by Limochi (2012) stating that the increase of branches by environmental condition optimization is occurred during the second date although it is minimal and insignificant (Table 3).evaluating the trend of variations, it can be concluded that this property is completely dependent on genotype because it had the minimum reaction to different dates of planting and the difference of varieties was more obvious, as the tall leg Anbori variety had the minimum variation and its number got fixed faster than other varieties, while, averagely, all varieties had a fixed trend from the sixth sampling. Most of the photosynthesis material was used for seed filling and increasing of the weight, which become more intense when the increase of branches number stops (Figure 1).

Table 2: Analysis of variance for Agronomy characteristics features and grain yield of the experimental treatments

\begin{tabular}{lllllll}
\hline S.O.V & df & $\begin{array}{l}\text { Panicle } \\
\text { length }\end{array}$ & $\begin{array}{l}\text { Dry weight } \\
\text { panicle }\end{array}$ & $\begin{array}{l}\text { floret in the } \\
\text { panicle }\end{array}$ & $\begin{array}{l}\text { branches in } \\
\text { the panicle }\end{array}$ & Grain yield \\
\hline Repeat & 2 & $1.833^{\text {n.s }}$ & $0.022^{\text {n.s }}$ & $214.333^{\text {n.s }}$ & $0.453^{\text {n.s }}$ & $7328.926^{\text {n.s }}$ \\
Sowing date & 2 & $1.201^{\text {n.s }}$ & $1.72^{* *}$ & $1981.778^{*}$ & $0.898^{\text {n.s }}$ & $6010778.926^{* *}$ \\
Error (a) & 4 & 0.728 & 0.01 & 478.443 & 0.676 & 12808.314 \\
Variety & 2 & $31.152^{* * *}$ & $0.30^{* *}$ & $974.332^{\text {n.s }}$ & $8.787^{*}$ & $684287.814^{\text {*** }}$ \\
variety $\times$ Sowing date & 4 & $0.430^{\text {n.s }}$ & $0.06^{*}$ & $379.110^{\text {n.s }}$ & $0.092^{\text {n.s }}$ & $85027.204^{\text {n.s }}$ \\
Error $(b)$ & 12 & 0.699 & 0.02 & 379.574 & 0.685 & 56022.963 \\
\hline $\mathrm{CV}(\%)$ & 3.26 & 5.06 & 11.39 & 8.55 & 6.74 \\
\hline \multicolumn{7}{c}{ ns, ${ }^{*}$ and ${ }^{* *}$ are nonsignificant and significant at the 5\% and 1\% levels of probability, respectively. }
\end{tabular}

Table 3: Comparison Agronomy characteristics features and grain yield of the experimental treatments

\begin{tabular}{lllllll}
\hline Factor & & $\begin{array}{l}\text { Panicle } \\
\text { length } \\
(\mathrm{cm})\end{array}$ & $\begin{array}{l}\text { Dry } \\
\text { weight } \\
\text { panicle } \\
(\mathrm{g})\end{array}$ & $\begin{array}{l}\text { floret in the } \begin{array}{l}\text { branches in } \\
\text { panicle } \\
\text { (number/ } \\
\text { panicle) }\end{array} \\
\text { the panicle } \\
\text { (number/ } \\
\text { panicle) }\end{array}$ & $\begin{array}{l}\text { Grain } \\
\text { yield } \\
(\mathrm{Kg} / \mathrm{ha})\end{array}$ \\
\hline \multirow{2}{*}{$\begin{array}{l}\text { Sowing } \\
\text { date }\end{array}$} & $\mathrm{d} 1$ & $25.77 \mathrm{a}$ & $2.21 \mathrm{c}$ & $159.22 \mathrm{a}$ & $9.77 \mathrm{a}$ & $2645.44 \mathrm{c}$ \\
& $\mathrm{d} 2$ & $25.91 \mathrm{a}$ & $2.48 \mathrm{~b}$ & $166.11 \mathrm{a}$ & $9.64 \mathrm{a}$ & $3618.1 \mathrm{~b}$ \\
\hline \multirow{3}{*}{ variety } & d3 & $25.22 \mathrm{a}$ & $3.06 \mathrm{a}$ & $187.67 \mathrm{a}$ & $9.33 \mathrm{a}$ & $4269.33 \mathrm{a}$ \\
\hline
\end{tabular}

There are other similar letters in each column, with Duncan's test is significant at $1 \%$ level. 
Table 4: Comparison Dry weight panicle in study rice varieties

\begin{tabular}{ccc}
$\begin{array}{c}\text { Planting } \\
\text { date }\end{array}$ & variety & $\begin{array}{c}\text { Dry weight panicle } \\
\text { (g) }\end{array}$ \\
\hline \multirow{4}{*}{ D1 } & V1 & $1.61 \mathrm{a}$ \\
& V2 & $1.50 \mathrm{ab}$ \\
& V3 & $1.34 \mathrm{~b}$ \\
& V1 & $1.53 \mathrm{a}$ \\
D2 & V2 & $1.46 \mathrm{ab}$ \\
& V3 & $1.28 \mathrm{~b}$ \\
& V1 & $1.46 \mathrm{ab}$ \\
D3 & V2 & $1.40 \mathrm{ab}$ \\
& V3 & $1.24 \mathrm{~b}$ \\
\hline
\end{tabular}

There are other similar letters in each column, with Duncan's test is significant at $1 \%$ level.

Table 5: Correlation coefficients between grain yield and Agronomy characteristics

\begin{tabular}{|c|c|c|c|c|c|}
\hline & $\begin{array}{l}\text { Panicle } \\
\text { length }\end{array}$ & $\begin{array}{l}\text { Dry weight } \\
\text { panicle }\end{array}$ & $\begin{array}{l}\text { floret in } \\
\text { the panicle }\end{array}$ & $\begin{array}{l}\text { branches in } \\
\text { the panicle }\end{array}$ & $\begin{array}{l}\text { Grain } \\
\text { yield }\end{array}$ \\
\hline Panicle length & 1 & & & & \\
\hline Dry weight panicle & 0.108 & 1 & & & \\
\hline floret in the panicle & -0.187 & 0.334 & 1 & & \\
\hline branches in the panicle & -0.358 & $-0.433^{*}$ & 0.300 & 1 & \\
\hline Grain yield & 0.090 & $0.759^{\circ *}$ & 0.367 & -0.186 & 1 \\
\hline
\end{tabular}

Grain yield: Grain yield significantly affected by planting date and varieties were significant differences in the level of error of one percent (Table 2) but the interaction of two factors, planting date and cultivar difference was not statistically significant and the lack heat of the figures and also increase the growth period of the first planting date to the third and increase the amount of carbohydrates and minerals is transferred to the grain. Between the highest figures in the performance of Champa with the $3795.4 \mathrm{~kg} / \mathrm{ha}$, respectively, which can be influenced by genotype characteristics, environmental factors and the outcome and their positive integration in the last figure is the ultimate in superior production capacity of the reservoir and the accumulation of active higher dry (grain 2012) based on increased performance is consistent with increasing period. Based storage $x$ seed number) in this figure compared to other varieties (Table 3).

The results are reported (Fox et al., 2004; Board et al., 2001; Farrell et al., 2004; Lewin et al., 2004; Naidu et al., 2004) based on temperature and (Limochion the table of correlation coefficients (Table 4), the performance of seed had the maximum positive and significant correlation $(0.759 * *)$ with panicle weight, and because of this property's direct effect, it can be important in the modifying process in order to gain the maximum seed performance. This is confirmed by Limochi (2012) stating the direct effect of panicle weight on the seed performance (Table 5).

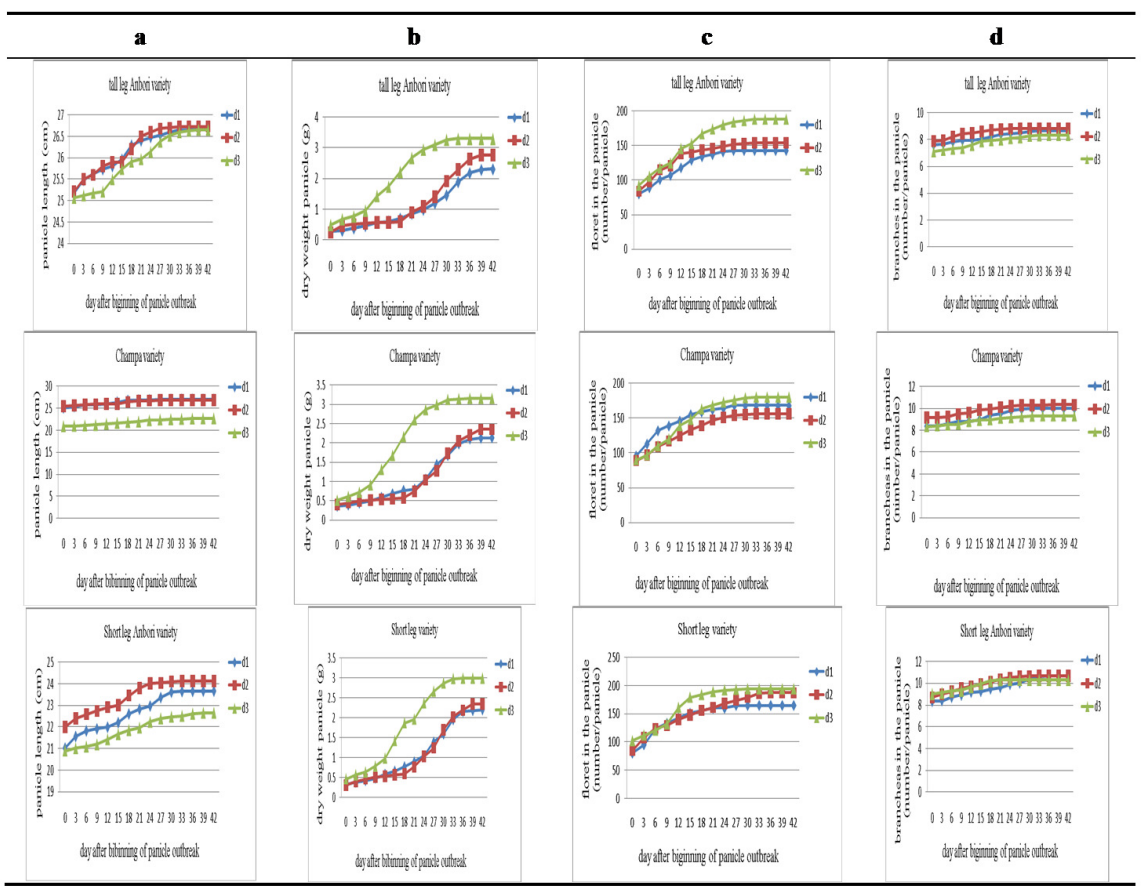

Fig. 1: variation in rice varieties` panicle a- panicle length, b- panicle`s dry weight, $c$ - trend of floret number, $d$ - Trend of branch number 


\section{REFERENCES}

Arfani, A., Nasiri, VM. (2000). Effect som of the morphological and physiology characteristics on the yield cultivars rice. Report Research station rice. Iran. Mozandaran. PP. 430.

Ali, MY., Rahman, MM. (1992). Effect of seedling age and transplanting time on late planted Aman rice. Bangladesh Journal of Training and Development 5: 75-83.

Board, JE., Peterson, ML., Ng, E. (2001). Floret Sterility in Rice in a Cool Environment. Journal of Agronomy. 72: 483-487.

Emam, Y. (2007). Cereals production. Shiraz, university. press. 199 pp. (In parsian).

Farrell, TC, Fox, KM., Williams, RI, Fukai, S., Lewin, LG. (2004). How to improve reproductive cold tolerance of rice in Australia. International Rice Cold Tolerance Workshop CSIRO Discovery, Canberra, 22-23 July.

Fox, KM., Subasinghe, R., Looby, PD., Wornes, DL. (2004). screening for Rice Cold Tolerance: Low temperature effects on flowering. $300 \mathrm{pp}$.

Gilani, A. (2010). Determination of tolerance mechanisms and physiological effect of heat stress in rice Cultivars of Khouzestan. Ph.D. Thesis of Agronomy and Natural Resources University of Ramin, Ahwaz, Iran. pp. 250. (In parsian).

Gilani, A., Moradi, f. (1996). study Possibility of rice planting in March, reports the Rice Research Agricultural Research Center of Khuzestan. Ahvaz. Iran. pp. 192. (In parsian).

Horie, T., Yoshida, H., Shiraiwa, T., Nakagawa, H., Kuroda, E., sasaki, T., Hagiwara, M., KObata, T., Ohnishi, M., Kobayashi, K. (2003). Analysis of benotype by environment interaction in yield formation processes of rice grown under a Wide environmental range in Asia. 10. Asia Rice Network (ARICENET) research and preliminary results. JPN. J. Crop Sci. 72 (Extra issue2): 88-89 (in Japanse).

Ismail, C. (1988). Analysis of yield and its components and of path coefficient inearly varieties of rice (oryza sativa). Cienciay Tecnica en la Agricultura, Arraz 11: (1) 7-17.

Lewin, L., Lacy, J., Ford, R., subasinghe, R. (2004). Rice Research Australia. Perceptions of rice cold damage $b$ farmers, Advisers and researchers. Rice of Researchers. 12: $42-54$.

Limochi, K. (2012). study of winter and summer planting dates on the flag leaf anatomy and yield of rice varieties in Khuzestan. M.Sc. Thesis of Agronomy, Collage of Agricultural, Islamic Azad University. Dezfoul. Iran. pp, 186. (In parsian).
Murchi, E., Jian chang, Y., Stella, H., Shaobing, P. (2002). Are there associations between grain filling rate and photosynthesis in the flag leaves of field grown rice. $J$. of exp. Botany. 53(378): 2217-2224.

Nagata, K., Hiroyuki, S., Tomio, t. (2002). Quantitative trait loci for Nonstructural carbohydrate accumulation in leaf sheaths and culms of rice (Oryza Sativa. L.) and their effects on grain filling. Breeding Science. 52:275283.

Naidu, BP., Gunawardena, TA., Fukai, S. (2004). Mechanism of cold tolerance ir rice at seedling and reproductive stages. $21 \mathrm{pp}$.

Nour-Mohamadi, G., Siadat, AS., Kashani, A. (2009). Agronomy cereal crops. Shahid chamran university. Iran. Ahwaz. pp. 446. (In parsian).

Peng, S., Garcia, FV., Laza, RC., Sanica, Ah., visperas, RM. (2004). and cassman yielding irrigated rice. Field crops of Research. 47:243-252.

Rafiee, M. (2007). Effect of Planting Date on Yield of some Rice Cultivars in Khorramabad Condition. Seed and Plant Production Journal. 24(2): 251-263.

Siadat, SA., Fathi, G., Hemaiaty, SS., Biranvand, M. (2004). Effect of planting dates on paddy yield and yield components in three rice cultivars. Iranian Journal of Agricultural Sciences. 35: 234-242 (In parsian).

Steven, D., Linscombe, D. (2004). Plant Management Network. Rioce Response to Planting Date Differs at Two Locations in Louisiana.

Wu, SZ., Huang, CW., Wuand, JQ., Zhong, YQ. (1987). Studies on varietal on varietal charactaris tics in cultivar sof oryza sativa.V.Correlation between genetic parameter sof the main character and selection in cultivars with good grain quality. Hereditas china 9:48.

Yang, J., Peng, S., Visporas, RM., Sanico, AL., ZhU, Q., CU, S. (2002). Grain filling pattern and Cytokinin content in the grain and roots of rice plants. Plant Growth and Regul. 30:261-270.

Yoshida, S., Conronel, V. (1976). Climatic influence on yield and yield components of lowland rice in the tropics. International Rice Research Institution (IRRI). P: 471-494.

Zakaria, S., Matsuda, T., Tajima, S., Nitta, Y. (2002). Effeect of high temperature at ripening stage reserve accumulation in seed in some rice cultivars. Plant prod. Sci. 5:160-168. 